ISSN : $1225-9918$

\title{
The Anti-Wrinkle and Whitening Effect of Extracts of Castanea crenata Inner Shell
}

Min-Jung Jang ${ }^{1}$, Soon-Ju Cheon ${ }^{2}$, Hui-Yeong Kim², Dae-Jun Kwoen ${ }^{3}$, Hak-Yoon Kim ${ }^{4}$ Sea-Hyun $\mathrm{Kim}^{5}$ and Jin-Tae $\mathrm{Lee}^{2}$ *

${ }^{1}$ ACM KOREA Co., Ltd, Gyeansan 712-210, Korea

${ }^{2}$ Department of Cosmeceutical Science, Daegu Haany University, Gyeonsan 712-715, Korea

${ }^{3}$ Biohealth convergence Center, Technopark, Daegu 704-801, Korea

${ }^{4}$ Department of Global Environment, Keimyung University, Daegu 704-701, Korea

${ }^{5}$ Department of Forest Resources Development, Korea Forest Research Institute, Suwon 441-847, Korea

Received February 17, 2011 /Accepted May 25, 2011

\begin{abstract}
Aging in humans is inexorable and inescapable. The progressive decrease of physiological capacity and the reduction of the ability to cope with environmental stresses lead to increased susceptibility and vulnerability to human disease. Recently, in the cosmetic industry, many researchers have paid considerable attention to delaying or improving the symptoms of skin aging. Since the early 1990's, there have been various challenges in developing cosmeceutical products which have strong anti-aging effects, and this has been an important issue in the cosmetic industry. Meanwhile, development of anti-aging cosmetics supported by biochemical activities in the skin has been researched. Castanea crenata inner Shell solvent extracts were investigated for anti-wrinkle and whitening effects, in order to apply it as a functional ingredient for cosmetic products. For anti-wrinkle effect, elastase inhibition activity of Castanea crenata inner shell acetone extract (CA) was $51.0 \%$ at a concentration of $100 \mathrm{ug} / \mathrm{ml}$. The collagenase inhibition activity of CA and Castanea crenata inner shell ethanol extract (CE) was $96.4 \%, 94.3 \%$ at a concentration of $50 \mathrm{ug} / \mathrm{ml}$. The tyrosinase inhibitory effect, which is related to skin-whitening, was $47.2 \%$ and $45.8 \%$ in CA and CE at a concentration of $500 \mathrm{ug} / \mathrm{ml}$. All these results suggest that Castanea crenata inner shell can be effectively used as a cosmeceutical ingredient for the prevention of wrinkles.
\end{abstract}

Key words : Castanea crenata inner Shell, anti-wrinkle, whitening

\section{서 론}

최근 우리나라는 생활수준의 향상으로 건강한 삶에 대한 관심이 꾸준히 증가하고 있으며, 이에 따라 질병의 예방 및 개선을 위해 동, 식물 등으로부터 얻어지는 생리활성 물질들 을 이용하려는 연구가 활발히 진행되고 있다[13].

특히 화장품 산업에는 약품의 기능이 첨가된 기능성화장품 혹은 약용화장품의 개념이 도입되어, 세계적으로 폭 넓게 이 용되고 있다[7]. 새로운 기능성화장품의 개발에서 원하는 활성 을 보유한 원료물질의 개발이 우선되어야 하며, 관심의 대상 이 되는 효과로 미백, 주름개선, 항산화 효과 등이 있다. 이러 한 효과를 보유한 물질을 천연소재에서 찾으려는 연구가 활발 하게 이루어지고 있다.

기능성 화장품은 막대한 시간과 자금이 투자되는 의약품보 다 상대적으로 적은 비용과 시간을 투자하여 세계적으로 경쟁 이 가능한 신제품 개발이 가능하고 시장 성장성과 고부가가치

*Corresponding author

Tel : +82-53-819-1430, Fax : +82-53-819-1430

E-mail : jtlee@dhu.ac.kr
창출에도 상당히 긍정적인 첨단 미래형 산업으로 인식되고 있다. 소비자들은 기능성화장품의 일시적 개선효과 보다는 가 시적이고 지속적인 미백 또는 주름개선 등 실질적인 효과를 요구하고 있으나, 현재까지 개발된 국내의 기능성화장품들은 이를 충분히 만족시켜주지 못하고 있다. 이는 식약청에서 고 시한 기능성화장품 원료 pool이 많지 않아 차별성에 한계가 있고 화학적인 원료의 부작용들이 보고되고 있기 때문이다. 이러한 문제점들을 극복하기 위하여 식물체 유래 천연물에서 기능성 화장품의 원료를 탐색하는 연구가 이루어지고 있다[6].

율피는 너도 밤나무과(Buna)의 다년생 초목인 밤나무 (Castanea crenataSieb)의 과실인 밤의 속껍질로 피부를 청결하 고 아름답게 하며 노화를 방지하는 것으로 알려졌다[15]. 율피 의 주요작용은 피부에 수분을 공급하거나 피부로부터 수분이 과도하게 증발되는 것을 막아주는 보습효과[17]와 특히, 유해 환경으로부터 신체 내부에 생성된 반응성이 높은 활성산소나 자유라디칼 과산화물에 의해 생체성분이 산화되거나 변성되 어 피부노화의 주원인으로 작용하는 것을 저해하거나 자유라 디칼 소거작용을 한다. 또한 율피는 DOPA 자동산화에 대한 저해작용, 피부의 과다한 멜라닌 색소 형성에 의한 피부의 색 
소 침착을 억제해주는 미백효과를 나타내며, 옛날부터 미용재 료로서 인정받아왔을 뿐 아니라, 민간에서도 많이 사용하고 있다[12].

지금까지 율피에 대해서는 대부분 임상학적 연구나 약리학 적 연구, 미백효과에 대한 연구는 많이 진행되어 있으나, 주름 개선 효과에 대한 내용은 보고된 바 없어 다음과 같은 실험을 실시하여 율피의 화장품산업에의 응용 시 기능성을 가지는 천연소재로서의 역할을 검토하였다.

\section{재료 및 방법}

\section{시료 제조}

본 실험에 사용된 율피는 충청남도 공주에서 채집하여 사용 하였다. 시료의 추출은 열수 추출물의 경우 시료에 증류수 10 배 양을 가하여 $85^{\circ} \mathrm{C}$ 에서 3시간 환류 냉각 추출하여 상등액과 침전물을 분리하여 3회 반복 추출하였으며, 에탄올 및 아세톤 추출물의 경우 $70 \%$ 에탄올과 아세톤을 시료 중량의 10 배 양을 가하여 실온에서 24 시간 침지하여 상징액과 침전물을 분리하 여 동일한 방법으로 3 회 반복 추출하였다. 각 추출물은 원심분 리 및 여과, 농축 후 동결건조하여 냉장실에 보관하면서 본 실험의 시료로 사용하였다.

\section{Elastase 저해활성 측정}

Elastase 저해활성 측정은 Cannell 등[1]의 방법에 따라 측 정하였다. 율피 추출물을 일정 농도가 되도록 조제하여 0.5 $\mathrm{ml}$ 씩 시험관에 취하고, $50 \mathrm{mM}$ tris- $\mathrm{HCl}$ buffer $(\mathrm{pH}$ 8.6)에 녹 인 porcine pancreas elastase $(2.5 \mathrm{U} / \mathrm{ml})$ 용액 $0.5 \mathrm{ml}$ 을 가한 후 $50 \mathrm{mM}$ tris- $\mathrm{HCl}$ buffer $(\mathrm{pH} 8.6)$ 에 녹인 기질 N-succinyl-(L-Ala)3-p-nitroanilide $(0.5 \mathrm{mg} / \mathrm{ml})$ 을 첨가하여 20 분간 반 응시켜 기질로부터 생성되는 p-nitroanilide의 생성량을 405 $\mathrm{nm}$ 에서 측정하였다. Elastase 저해 활성은 시료용액의 첨가구 와 무첨가군의 흡광도 감소율로 나타내었다.

\section{Collagenase 저해활성 측정}

Collagenase 저해활성 측정은 Wûnsch 등[14]의 방법에 따 라 측정하였다. 즉 반응구는 $0.1 \mathrm{M}$ tris- $\mathrm{HCl}$ buffer $(\mathrm{pH}$ 7.5)에 $4 \mathrm{mM} \mathrm{CaCl}$ 를 첨가하여, 4-phenylazobenzyloxycarbonylPro-Leu-Gly-Pro-D-Arg $(0.3 \mathrm{mg} / \mathrm{ml})$ 를 녹인 기질액 $0.25 \mathrm{ml}$ 및 시료용액 $0.1 \mathrm{ml}$ 의 혼합액에 collagenase $(0.2 \mathrm{mg} / \mathrm{ml})$ $0.15 \mathrm{ml}$ 를 첨가하여 실온에서 20분간 정치한 후 $6 \%$ citric acid $0.5 \mathrm{ml}$ 을 넣어 반응을 정지 시킨 후, ethyl acetate $1.5 \mathrm{ml}$ 을 첨가하여 $320 \mathrm{~nm}$ 에서 흡광도를 측정하였다. Collagenase 저 해활성은 시료용액의 첨가구와 무첨가구의 흡광도 감소율로 나타내었다.

\section{Tyrosinase 저해활성 측정}

Tyrosinase 저해활성 측정은 Yagi 등의 방법[15]에 따라 측
정하였다. 반응구는 $0.175 \mathrm{M}$ sodium phosphate buffer $(\mathrm{pH}$ 6.8) $0.5 \mathrm{ml}$ 에 $10 \mathrm{mM} \mathrm{L-DOPA}$ 를 녹인 기질액 $0.2 \mathrm{ml}$ 및 시료용 액 $0.1 \mathrm{ml}$ 의 혼합액에 mushroom tyrosinase $(110 \mathrm{U} / \mathrm{ml}) 0.2$ $\mathrm{ml}$ 을 첨가하여 $25^{\circ} \mathrm{C}$ 에서 2 분간 반응시켜 반응액 중에 생성된 DOPA chrome을 $475 \mathrm{~nm}$ 에서 측정하였다. Tyrosinase 저해활 성은 시료용액의 첨가구와 무첨가구의 흡광도 감소율로 나타 내었다.

\section{통계처리}

실험 결과는 3회 반복 측정 후 평균 $\pm \mathrm{SD}$ 로 나타내었다. 통계 분석은 SAS program (SAS Institue, Cary, NC, USA)을 이용 하여 분석한 후 Duncan의 다중검정을 실시하였으며, 상관관 계를 분석하였다.

\section{결 과}

\section{Elastase 저해활성 측정}

Elastase는 단백질인 엘라스틴을 분해하는 효소로 다른 중 요한 기질 단백질인 콜라겐을 분해할 수 있는 비특이적 가수 분해 효소이다. 피부의 진피조직 속에는 collagen과 피부의 탄 력성에 관련된 elastin이 그물망 구조를 형성하고 있는데, elastin이 elastase에 의해 분해되어 피부의 그물망 구조 결합이 끊어짐으로, elastase가 주름생성의 주원인 효소로 알려져 있 다[7]. Elastase 저해제는 피부 주름을 개선하는 작용을 나타내 고, ursolic acid등이 elastase 저해제로 이용되고 있다[13]. 이 러한 주름 생성과 관련한 elastase 저해활성을 측정한 결과 Fig. 1과 같다. 율피 열수 추출물 $100 \mathrm{ug} / \mathrm{ml}$ 의 경우 $10.0 \%$ 이하 의 낮은 활성을 나타낸 반면 율피 아세톤 및 에탄올 추출물 $100 \mathrm{ug} / \mathrm{ml}$ 의 경우 $51.0 \%, 35.4 \%$ 의 elastase 저해활성을 나타 내었다. 특히 율피 아세톤 추출물의 경우 동일 농도의 대조군 인 ursolic acid 보다 elastase 저해활성이 높은 것으로 나타났 으며, Kwak [8] 등의 각종 약용 식물로부터 elastase 저해활성 을 측정한 결과, 대부분이 $100 \mathrm{ug} / \mathrm{ml}$ 에서 $30 \%$ 미만의 저해활 성을 나타낸 것과 비교 시 율피 아세톤 추출물이 높은 저해율 을 나타내었다.

\section{Collagenase 저해활성 측정}

콜라겐은 대부분 피부의 진피층에 존재하며, 피부 전체 건 조중량의 약 70 80\%를 차지하고 있어, 세포외 기질의 대부분 을 차지하면서 피부를 지지하는 역할을 한다. 그러나 자연 노 화에 따른 세포 활성의 감소와 같은 내적 요인에 의해 콜라겐 의 생합성이 감소되고, 여러 가지 유해 환경에 의한 스트레스 의 증가 및 태양 광선에 의한 활성 산소종의 증가와 같은 외적 요인에 의해 분해가 가속화되어 피부 기질이 파괴되면서 주름 이 생성된다[5]. 본 실험에서 율피 추출물에 대한 collagenase 저해활성을 측정한 결과 $50 \mathrm{ug} / \mathrm{ml}$ 에서 열수추출물의 경우 


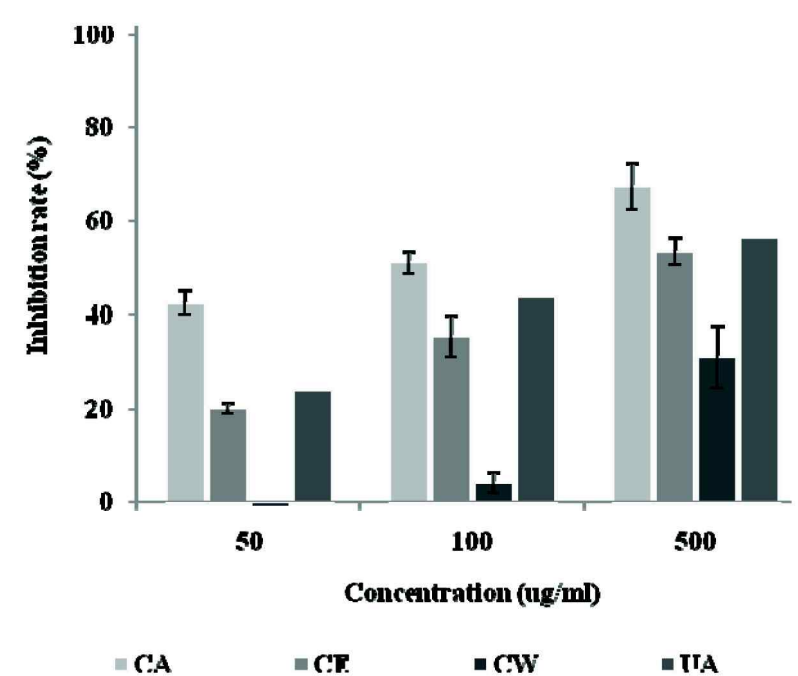

Fig. 1. Inhibition rate of Castanea crenata inner Shell extracts on elastase. CA: Castanea crenata inner Shell extracted with acetone, CE: Castanea crenata inner Shell extracted with ethanol, CW: Castanea crenata inner Shell extracted with water, UA:Ursolic acid

$63.8 \%$ 의 저해활성을 나타낸 반면, 아세톤 및 에탄올 추출물의 경우 $96.4 \%, 94.3 \%$ 의 저해활성을 나타내어 대조군으로 사용한 EGCG $50 \mathrm{ug} / \mathrm{ml}$ 에서의 저해효과보다 우수한 결과를 보였고, Kang [4] 등의 토사자, 음양곽, 건지황이 $250 \mathrm{ug} / \mathrm{ml}$ 에서 각각 $40 \%, 37.5 \%, 35 \%$ 로 나타나 율피추출물의 collagenase 저해활 성이 더 우수함을 확인할 수 있었다(Fig. 2).

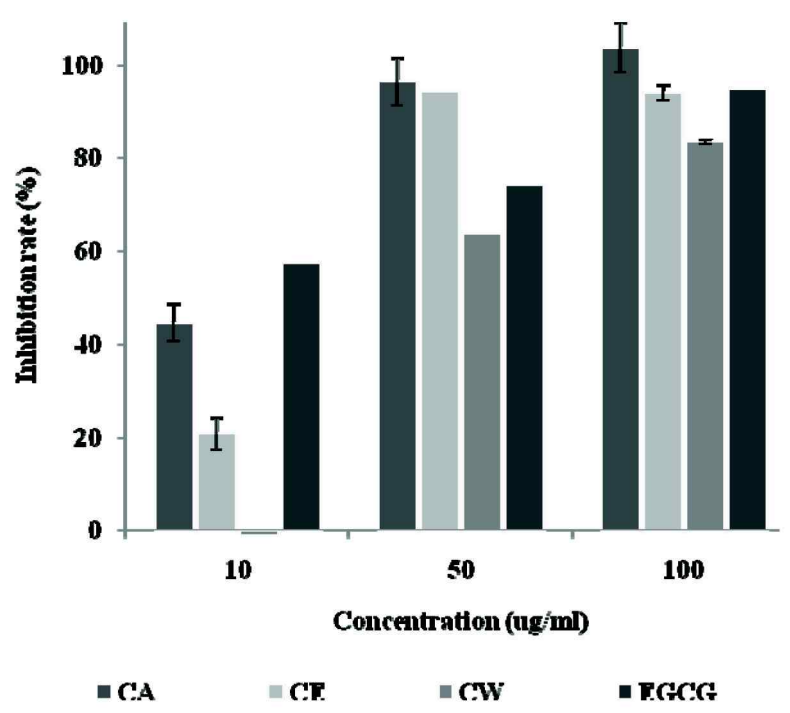

Fig. 2. Inhibition rate of Castanea crenata inner Shell extracts on collagenase. CA: Castanea crenata inner Shell extracted with acetone, CE: Castanea crenata inner Shell extracted with ethanol, CW: Castanea crenata inner Shell extracted with water, EGCG: epigallocatechin-3-gallate

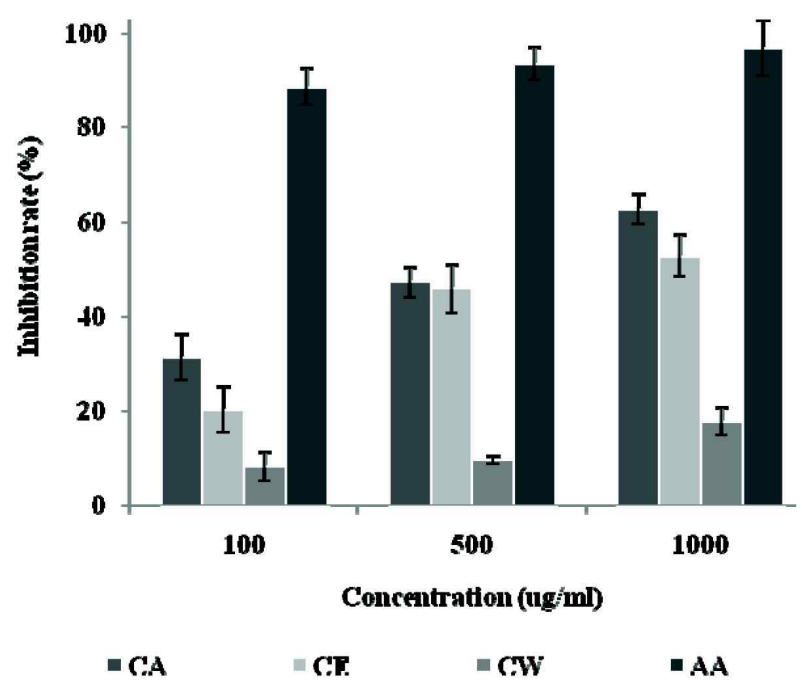

Fig. 3. Inhibition rate of Castanea crenata inner Shell extracts on tyrosinase. CA: Castanea crenata inner Shell extracted with acetone, CE: Castanea crenata inner Shell extracted with ethanol, CW: Castanea crenata inner Shell extracted with water, AA: L-ascorbic acid

Tyrosinase 저해능

Tyrosinase는 피부 멜라닌 생성에 있어서 매우 중요한 역할 을 하고 있으며, 이런 tyrosine 활성 억제제는 피부 내에서의 melanin polymer 합성을 효과적으로 저해할 수 있어 피부 미 백제의 개발에 있어서 tyrosinase 활성억제 실험은 유용한 평 가법으로 인정되고 있다[3,11]. 이렇게 피부 내에서 멜라닌 중 합체 생합성을 효과적으로 저해할 수 있는 tyrosinase 저해활 성을 측정한 결과 Fig. 3 과 같이 나타내었다. 율피 용매별 추출 물의 tyrosinase 저해능은 collagenase 저해활성과 같이 아세 톤 및 에탄올 추출물이 열수 추출물보다 높은 tyrosinase 저해 활성을 나타내었으며, 그 효과는 $500 \mathrm{ug} / \mathrm{ml}$ 에서 아세톤 추출 물이 $47.2 \%$, 에탄올 추출물이 $45.8 \%$ 의 효과를 나타내었으며, 대조군으로 사용한 L-ascorbic acid는 $90 \%$ 로 가장 높은 tyrosinase 활성 억제율을 나타내었다. 이는 기능성 화장품원료 로 사용되는 알부틴의 $\mathrm{IC}_{50}$ 이 $2.04 \%$ 와 비교시 율피 추출물의 tyrosinase의 활성억제율이 우수한 것으로 나타났다.

\section{결론 및 고찰}

본 연구에서는 시험관 실험을 통해 밤나무의 열매일 밤의 속껍질을 기능성화장품 소재로 활용하고자 elastase저해활성, collagenase 저해활성을 통하여 주름개선효과를 검증하였으 며, 미백효과를 확인하기 위하여 tyrosinase 저해활성을 측정 하였다.

Tyrosinase 저해활성 실험에서 대조군으로 사용한 L-ascrobic acid가 tyrosinase 활성 억제율이 가장 높게 나타났으 
며, 율피 추출물인 $\mathrm{CA}, \mathrm{CE}, \mathrm{CW}$ 의 농도가 증가함에 따라 tyrosinase의 활성 억제율이 증가되었다. 그 중 $\mathrm{CA}$ 는 가장 높은 tyrosinase 저해활성을 나타내었으며, 기존의 율피로 연구되 어진 tyrosinase 활성 억제실험과 비교시 CA가 가장 높은 tyrosinase 저해효과가 있음을 확인하였다.

주름개선 효과를 검증하기 위하여 elastase 저해활성과 collagenase 저해활성을 측정한 결과, tyrosinase 저해활성 시험 과 같이 $\mathrm{CA}$ 의 주름개선효과가 뛰어남을 확인할 수 있었다.

그 중 elastase 저해활성 측정한 결과 $\mathrm{CA}$ 는 $50 \mathrm{ug} / \mathrm{ml}$ 에서 $40.0 \%$ 이상의 효과를 나타내었으며, 이는 대조군으로 UA보다 2 배 이상의 elastase저해활성을 나타내어 우수한 주름개선 효 과가 있음이 확인 되었으며, collagenase 저해활성도 CA 50 $\mathrm{ug} / \mathrm{ml}$ 에서 $96.4 \%$ 의 저해활성을 나타내어 우수한 주름개선효 과가 있음을 확인할 수 있었다.

이상의 실험결과 율피 추출물이 미백활성과 주름개선효과 와 주름개선 효과를 동시에 나타내며, 특히 collagenase 저해 활성이 뛰어나 주름개선 기능성 원료로 활용가능성이 높은 것으로 판단된다.

\section{감사의 글}

본 연구는 산림청 '산림과학기술개발사업(과제번호: S121010L060110'의 지원에 의하여 이루어진 것입니다.

\section{References}

1. Cannell, R. J., S. J. Kellam, A. M. Owsianks, and J. M. Malker. 1988. Results of a large scale screen of microalgae for the production of protease inhibitors. Planta Med 54, 10-14.

2. Gomes, A., J. R. Vedasiromoni, M. Das, R. M. Sharma, and D. K. Ganguly. 1995. Anti-hyperglycemic effect of black tea (Camelliasinensis) inrat. J. Ethnopharmacol. 45, 223-226.

3. Imokawa, G. and Y. Mishima. 1981. Biochemical characterization of tyrosinase inhibitors using tyrosinase binding affinity chromatography. Br. J. Dermatol. 104. 513-539.

4. Kang, K. S. 2007. The Evalution of Anti-wrinkle Effects in Oriental herb extract. J. Life Sci. 17, 1147-1151.
5. Kim, S. N., S. H. Lee, B. K. Lee, and I. S. Jang. 2002. A compositions containing Anthriscus sylvestris Hoffmann extract or Petroselinum sativum Miller extract for external application having effects of improving skin wrinkle. Korea Institute of Patent Information. 10-2002-0079594

6. Kim, Y. G., Y. H. Lee, M. K. Kang, B. H. Lee, J. K. Yun, S. B. Kim, and C. J. Kim. 2009. Preparation of functional cosmetics containing $\beta$-carotene derived from recombinant Escherichia coil and evaluation of anti-wrinkle efficacy by clinical testing. Korean J. Microbiol. Biotechnol. 37, 399-404.

7. Kligman, D. 2000. Cosmeveuticals. Dermatol. Clin. 18, 609-615.

8. Kwak, Y. J., D. H. Lee, N. M. Kim, and J. S. Lee. 2005. Screeing and extraction condition of anti-skin aging elastase inhibitor from medicinal plants. Korean J. Medicinal Crop Sci. 13, 213-216.

9. Lee, S. Y., J. H. An, and H. Y. Cho. 2003. Isolation and characterization of MMP-1 inhibitor Peptide from Crataegus pinnatificla bunge in fibroblast cell line HS68 cells. J. Korean Soc. Agric. Chem Biotechnol. 46, 60-65.

10. Park, A. Y. 2009. Effects of Extracts from Chestnut Inner Shell on Skin Catholic University. Daegu, Korea.

11. Seong, J. K. 2007. Lignan glycosides of vaccinium oldhami Miquel. Korean J. Pharmacognosy 38, 296-298.

12. Suk, C. H. 1997. Pharmaceutical characteristics and dermatophysiological effects of cosmeceuticals containing Chestnut bark extracts. Chungang University. Seoul. Korea.

13. Tsuji, N., S. Moriwaki, Y. Suzuki, Y. Takema, and G. Imokawa. 2001. The role of elastases secreted by fibroblasts in wrinkle formation: implication through selective inhibition of elastase activity. Photochem Photobiol. 74, 283-290.

14. Wúnsch, E. and H. G. Heidrich. 1963. Zur quantitativen bestimmung der kollagenase. Hoppe-Seyler's. Physiol. Chem 333. 149-151.

15. Yagi, A., T. Kanbara, and N. Morinobu. 1986. The effect of tyrosinase inhibition for aloe. Planta Medica. 3981, 517-519.

16. Yang, M. J., S. J. Lim, H. S. Ahn, M. A. Kim, and R. M. Ahn. 1999. Inhibitory effect of Chestnut bark extracts on tyrosinase activity and melanin biosynthesis. Korean J. Env. Hth Soc. 25, 37-43.

17. Yoon, W. J. 1997. The study on the hemidity preserving effect with several natural packs, Dongduk womens University. Seoul, Korea. 


\section{초록 : 밤부산물(율피)의 주름개선 및 미백 효과}

장민정 ${ }^{1} \cdot$ 천순주 $^{2} \cdot$ 김희영 ${ }^{2}$ 권대준 ${ }^{3} \cdot$ 김학윤 ${ }^{4} \cdot$ 김세현 $^{5} \cdot$ 이진태 $^{2} \star$

(1(주)아쎄엠코리아 연구소, ${ }^{2}$ 대구한의대학교 화장품약리학과, ${ }^{3}$ 대구테크노파크 바이오헬스융합센터, ${ }^{4}$ 계명대 학교 환경생물학, ${ }^{5}$ 국립산림과학원 산림자원육성부)

율피를 기능성 화장품 소재로 활용하기 위하여 주름개선, 미백 및 수렴효과를 검증하였다. 주름개선 효과를 검증하기 위하여 elastase 저해활성과 collagenase 저해활성을 측정하였다. Elastase 저해활성을 측정한 결과 율피 아세톤 추출물 $100 \mathrm{ug} / \mathrm{ml}$ 에서 $51.0 \%$ 의 효과를 나타내었으며, collagenase 저해활성을 측정한 결과 아세톤 및 에 탄올 추출물이 $50 \mathrm{ug} / \mathrm{ml}$ 에서 $96.4 \%, 94.3 \%$ 의 저해활성을 나타내었다. 미백효과를 확인하기 위하여 tyrosinase 저해활성을 측정한 결과 아세톤 및 에탄올 추출물이 열수 추출물보다 높은 Tyrosinase 저해활성을 나타내었으나 대조군으로 사용한 Vitamin C와 비교시 약 $50 \%$ 의 효과를 나타내었다. 이상의 결과로 미루어 보아 율피 추출물의 주름개선 효과가 높음을 확인할 수 있었고, 주름개선 기능성 화장품 소재로서의 가능성을 확인하였다. 